\title{
Americium/Curium Extraction from Lanthanide Borosilicate Glass
}

\section{CONF-9(6)202--}

by

T. S. Rudisill

Westinghouse Savannah River Company

Savannah River Site

Aiken, South Carolina 29808

J. M. Pareizs

W. G. Ramsev

\section{8}

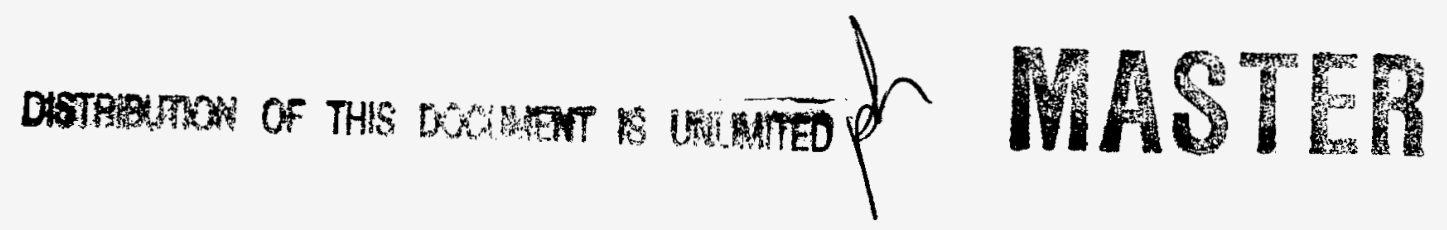

A document prepared for MATERIALS RESEARCH SOCIETY 1996 FALL MEETING at Boston, MA, USA from 12/2/96 - 12/6/96.

\section{DOE Contract No. DE-AC09-89SR18035}

This paper was prepared in connection with work done under the above contract number with the U. S. Department of Energy. By acceptance of this paper, the publisher and/or recipient acknowledges the U. S. Government's right to retain a nonexclusive, royalty-free license in and to any copyright covering this paper, along with the right to reproduce and to authorize others to reproduce all or part of the copyrighted paper. 


\section{DISCLAIMER}

This report was prepared as an account of work sponsored by an agency of the United States Government. Neither the United States Government nor any agency thereof, nor any of their employees, makes any warranty, express or implied, or assumes any legal liability or responsibility for the accuracy, completeness, or usefulness of any information, apparatus, product, or process disclosed, or represents that its use would not infringe privately owned rights. Reference herein to any specific commercial product, process, or service by trade name, trademark, manufacturer, or otherwise does not necessarily constitute or imply its endorsement, recommendation, or favoring by the United States Government or any agency thereof. The views and opinions of authors expressed herein do not necessarily state or reflect those of the United States Government or any agency thereof.

This report has been reproduced directly from the best available copy.

Available to DOE and DOE contractors from the Office of Scientific and Technical Information, P. O. Box 62, Oak Ridge, TN 37831; prices available from (423) 576-8401.

Available to the public from the National Technical Information Service, U. S. Department of Commerce, 5285 Port Royal Road, Springfield, VA 22161. 


\title{
AMERICIUM/CURIUM EXTRACTION FROM \\ A LANTHANIDE BOROSILICATE GLASS
}

\author{
T. S. RUDISILL, J. M. PAREIZS, and W. G. RAMSEY \\ Westinghouse Savannah River Company
}

\begin{abstract}
A solution containing kilogram quantities of highly radioactive isotopes of americium and curium $(\mathrm{Am} / \mathrm{Cm})$ and lanthanide fission products is currently stored in a process tank at the Department of Energy's Savannah River Site (SRS). This tank and its vital support systems are old, subject to deterioration, and prone to possible leakage. For this reason, a program has been initiated to stabilize this material as a lanthanide borosilicate (LBS) glass. ${ }^{1}$ The $\mathrm{Am} / \mathrm{Cm}$ has commercial value and is desired for use by the heavy isotope programs at the Oak Ridge National Laboratory (ORNL).

A recovery flowsheet was demonstrated using a curium-containing glass to extract the $\mathrm{Am} / \mathrm{Cm}$ from the glass matrix. The procedure involved grinding the glass to less than 200 mesh and dissolving in concentrated nitric acid at $110^{\circ} \mathrm{C}$. Under these conditions, the dissolution was essentially $100 \%$ after 2 hours except for the insoluble silicon. Using a nonradioactive surrogate, the expected glass dissolution rate during $\mathrm{Am} / \mathrm{Cm}$ recovery was bracketed by using both static and agitated conditions. The measured rates, 0.0082 and $0.040 \mathrm{~g} / \mathrm{hr}^{\mathrm{c}} \mathrm{cm}^{2}$, were used to develop a predictive model for the time required to dissolve a spherical glass particle in terms of the glass density, particle size, and measured rate. The calculated dissolution time was in agreement with the experimental observation that the curium glass dissolution was complete in less than $2 \mathrm{hr}$.
\end{abstract}

\section{INTRODUCTION}

Approximately $15,000 \mathrm{l}$ of solution containing isotopes of $\mathrm{Am} / \mathrm{Cm}$ are currently stored in the F-Canyon facility at the SRS. These isotopes were recovered during plutonium-242 production campaigns in the mid and late 1970's. The continued storage of this solution was identified as an item of urgent concern in the Defense Nuclear Facility Safety Board's Recommendation 94-1. Currently there are no existing SRS facilities which can be used to stabilize this material for safe long-term storage or transport to the heavy isotope programs at ORNL. An analysis of several alternatives has resulted in the recommendation to stabilize the $\mathrm{Am} / \mathrm{Cm}$ in a LBS glass. The Multi-Purpose Processing Facility in F-Canyon will be used for the vitrification process. Pretreatment operations will be performed in canyon vessels to separate the actinides and lanthanides from other metal impurities before subsequent vitrification.

Once the $\mathrm{Am} / \mathrm{Cm}$ solution is stabilized, the glass can be shipped to the Isotope Production and Distribution Program at ORNL for californium-252 production and for use by the transplutonium research community. These potential uses will require the dissolution and recovery of the $\mathrm{Am} / \mathrm{Cm}$ isotopes. For this reason, feasibility experiments were conducted to demonstrate the dissolution of the glass and solubilization of the $\mathrm{Am} / \mathrm{Cm}$. The dissolution flowsheet was based on the existing ORNL procedure for the recovery of $\mathrm{Am} / \mathrm{Cm}$ from transplutonium production targets. The targets are typically dissolved in nitric acid using a stainless steel dissolver in the ORNL hot cells. The dissolver can be sparged with air to provide a limited amount of agitation. 


\section{EXPERIMENT}

The feasibility of recovering $\mathrm{Am} / \mathrm{Cm}$ from a LBS glass was demonstrated using a curiumcontaining glass prepared to simulate the glass composition proposed for stabilizing the solution stored at the SRS. The dissolution rate of a nonradioactive surrogate was also measured using static and agitated conditions to bracket the dissolution rate which would be expected in a dissolver at ORNL. The design for each experiment is described below.

\section{Curium Extraction Test}

The radioactive glass used in the curium extraction test was prepared to simulate the target (baseline) composition proposed for use in stabilizing the $\mathrm{Am} / \mathrm{Cm}$ solution stored in F-Canyon. A comparison of the simulated and target compositions is shown in Table I.

Table I Composition of Curium and Target Am/Cm Glasses

\begin{tabular}{ccr}
\hline Oxide & $\begin{array}{c}\text { Curium Glass } \\
(\text { wt \%) }\end{array}$ & $\begin{array}{r}\text { Target Composition } \\
\text { (wt\%) }\end{array}$ \\
\hline $\mathrm{SiO}_{2}$ & 27.50 & 28.70 \\
$\mathrm{~B}_{2} \mathrm{O}_{3}$ & 5.02 & 5.97 \\
$\mathrm{Al}_{2} \mathrm{O}_{3}$ & 4.10 & 3.92 \\
$\mathrm{BaO}$ & 5.41 & 5.85 \\
$\mathrm{PbO}$ & 10.50 & 15.82 \\
$\mathrm{La}_{2} \mathrm{O}_{3}$ & 8.85 & 9.08 \\
$\mathrm{CeO}_{2}$ & 5.62 & 5.34 \\
$\mathrm{Pr}_{2} \mathrm{O}_{3}$ & 6.71 & 5.08 \\
$\mathrm{Nd}_{2} \mathrm{O}_{3}$ & 13.30 & 10.77 \\
$\mathrm{Sm}_{2} \mathrm{O}_{3}$ & 2.90 & 2.52 \\
$\mathrm{Eu}_{2} \mathrm{O}_{3}$ & 0.56 & 0.50 \\
$\mathrm{Gd}_{2} \mathrm{O}_{3}$ & 1.38 & 1.25 \\
$\mathrm{Cm}_{2} \mathrm{O}_{3}$ & 0.65 & 1.08 \\
Other $\mathrm{Actinides}^{\dagger}$ & -- & 4.12 \\
\hline
\end{tabular}

$\dagger$ Other Actinides in the glass include $\mathrm{AmO}_{2}, \mathrm{PuO}_{2}$, and $\mathrm{UO}_{3}$.

The curium extraction test was performed by placing $0.25 \mathrm{~g}$ of $-200 \mathrm{mesh}(\leq 74 \mu \mathrm{m})$ glass into each of six Teflon ${ }^{\mathrm{TM}}$ vessels containing $10 \mathrm{ml}$ of concentrated $(15.7 \mathrm{M})$ nitric acid. The vessels were sealed, weighed, and placed in an oven at $110^{\circ} \mathrm{C}$. After $2 \mathrm{hr}, 2$ vessels were removed for analysis, followed by 2 more at 4 and $8 \mathrm{hr}$. After cooling each vessel was opened and the contents transferred to a $250 \mathrm{ml}$ flask for dilution with $0.01 \mathrm{M}$ nitric acid. Samples were then analyzed by induction-coupled plasma emission (ICP-ES) and gamma spectroscopy.

\section{Glass Dissolution Rate}

The dissolution rate of a $38 \mathrm{wt} \%$ LBS glass was determined by measuring the mass and surface area during the dissolution as functions of time. The composition of the glass is shown in Table II. 
Table II Composition of 38 wt\% LBS Glass

\begin{tabular}{cc}
\hline Oxide & $\begin{array}{c}\text { Composition } \\
\text { (wt\%) }\end{array}$ \\
\hline $\mathrm{La}_{2} \mathrm{O}_{3}$ & 15 \\
$\mathrm{CeO}_{2}$ & 7 \\
$\mathrm{Nd}_{2} \mathrm{O}_{3}$ & 16 \\
$\mathrm{SiO}_{2}$ & 29 \\
$\mathrm{Al}_{2} \mathrm{O}_{3}$ & 17 \\
$\mathrm{PbO}$ & 9 \\
$\mathrm{BaO}$ & 4 \\
$\mathrm{~B}_{2} \mathrm{O}_{3}$ & 3 \\
\hline
\end{tabular}

Approximately $30 \mathrm{~g}$ of glass were initially melted and cast into a $2 \mathrm{~cm}$ diameter graphite crucible. The bottom and top of the glass were cut and polished to produce a right circular cylinder. The glass sample was placed in $8 \mathrm{M}$ nitric acid at nominally $110^{\circ} \mathrm{C}$. Periodically, the sample was removed from the acid, rinsed in distilled water, and dried. The sample mass, radius, and height were then measured as a function of the dissolution time. This procedure was initially performed using an air sparge for agitation and with removal of the silica layer from the surface of the glass prior to the measurements. The rate measured under these conditions corresponded to the most rapid dissolution which would be expected in the ORNL dissolver. This procedure was then repeated using the same glass sample with no agitation in the dissolver or removal of silica from the surface of the glass. These conditions corresponded to the slowest expected rate thereby bracketing the actual dissolution rate in the ORNL dissolver.

\section{RESULTS}

\section{Curium Extraction Test}

Results from the curium extraction test are presented in Table III as the percent of each element recovered from the glass as a function of heating time. The percentages were calculated from the concentrations of the respective elements in the final extraction solutions and the concentrations of the elements in the original glass. The analyzed composition of the glass was used for this calculation except for praseodymium which could not be analyzed due to spectral interferences. The quantity of praseodymium added to the glass batch was used for this calculation. The values shown in Table III are the average of two samples at each extraction time. The results for the duplicate samples were in excellent agreement. Relative standard deviations were nominally $\pm 5 \%$. From these results, it can be seen that all elements excluding silicon can be extracted from the glass in $2 \mathrm{hr}$ or less if the glass is ground to less than 200 mesh. The slightly greater than $100 \%$ recoveries are likely due to a low bias in the analyzed composition of the glass. Elemental analysis for the curium glass was performed following a sodium peroxide fusion and nitric acid dissolution. This technique only accounted for approximately $93 \%$ of the glass in the original sample (see Table I) which would inflate the recoveries given in Table III. The silicon in the glass which remained essentially insoluble, can be removed from the solution by filtration. 
Table III Elemental Recovery from a Curium-Containing Glass

\begin{tabular}{cccc}
\hline Element & $\begin{array}{c}\text { Recovery }-2 \mathrm{hr} \\
(\%)\end{array}$ & $\begin{array}{c}\text { Recovery }-4 \mathrm{hr} \\
(\%)\end{array}$ & $\begin{array}{c}\text { Recovery }-8 \mathrm{hr} \\
(\%)\end{array}$ \\
\hline Boron & 96.3 & 97.1 & 98.9 \\
Aluminum & 98.6 & 101.2 & 105.7 \\
Barium & 99.2 & 104.1 & 107.6 \\
Lead & 100.9 & 103.6 & 106.4 \\
Lanthanum & 107.2 & 107.4 & 108.6 \\
Cerium & 102.7 & 101.0 & 102.5 \\
Neodymium & 103.2 & 103.3 & 104.5 \\
Samarium & 103.9 & 103.5 & 104.6 \\
Europium & 106.2 & 106.1 & 107.2 \\
Gadolinium & 104.6 & 103.2 & 105.0 \\
Curium & 102.8 & 93.7 & 106.5 \\
\hline
\end{tabular}

\section{Glass Dissolution Rate}

Since the actual geometry and conditions used at ORNL for transplutonium target-dissolution could not be exactly duplicated in the laboratory, rate measurement experiments were designed to bracket the expected rate. Rapid and slow dissolution rates of the $38 \mathrm{wt} \%$ LBS glass were determined by plotting the ratio of the glass mass to surface area as a function of time and fitting least squares lines to the data (see Figures 1 and 2). The measured rates (-slope of the lines), at $95 \%$ confidence levels, were $0.040 \pm 0.002$ and $0.0082 \pm 0.0002 \mathrm{~g} / \mathrm{hr} \cdot \mathrm{cm}^{2}$.

The more aggressive conditions achieved during rapid dissolution were established by sparging with air and removing the silica layer which formed on the surface of the glass. The exposed surface area enhanced the rate by removing any barrier silica presented for diffusion of acid to the surface of the glass. Energy dispersive x-ray analysis confirmed the residue was pure silica and that all other components of the surrogate glass dissolved in $8 \mathrm{M}$ nitric acid. During the static dissolution test, care was taken not to remove the silica layer; however, silica did flake from the surface and built-up on the bottom of the dissolver. As the silica cracked and flaked from the surface, there was continual renewal of the layer as the dissolution proceeded. Although a silica layer formed on the surface of the glass and was either removed or flaked from the glass cylinder, right circular geometry was maintained throughout both experiments.

Once the glass sample was completely dissolved, the solution and residual solids were separated by filtration. The volume of the filtrate was measured and samples analyzed by ICP-ES for elemental concentrations. The residual solids were washed with $0.5 \mathrm{M}$ nitric acid to redissolve precipitated lead and barium nitrates. The solution was filtered and samples submitted for elemental analysis by ICP-ES. Based on the solution analyses, the recovery of each lanthanide was $100 \%$ with an overall elemental recovery (excluding silicon) of approximately $95 \%$. The silicon concentration in the dissolver solution was approximately $20 \mathrm{mg} / 1$.

\section{Glass Dissolution Model}

A predictive equation for the time required to dissolve a glass particle of spherical geometry was derived from the slope $\left(-K_{R}\right)$ of the line (equation 1$)$ through the data on Figures 1 and 2. 
Figure 1 Rapid Glass Dissolution

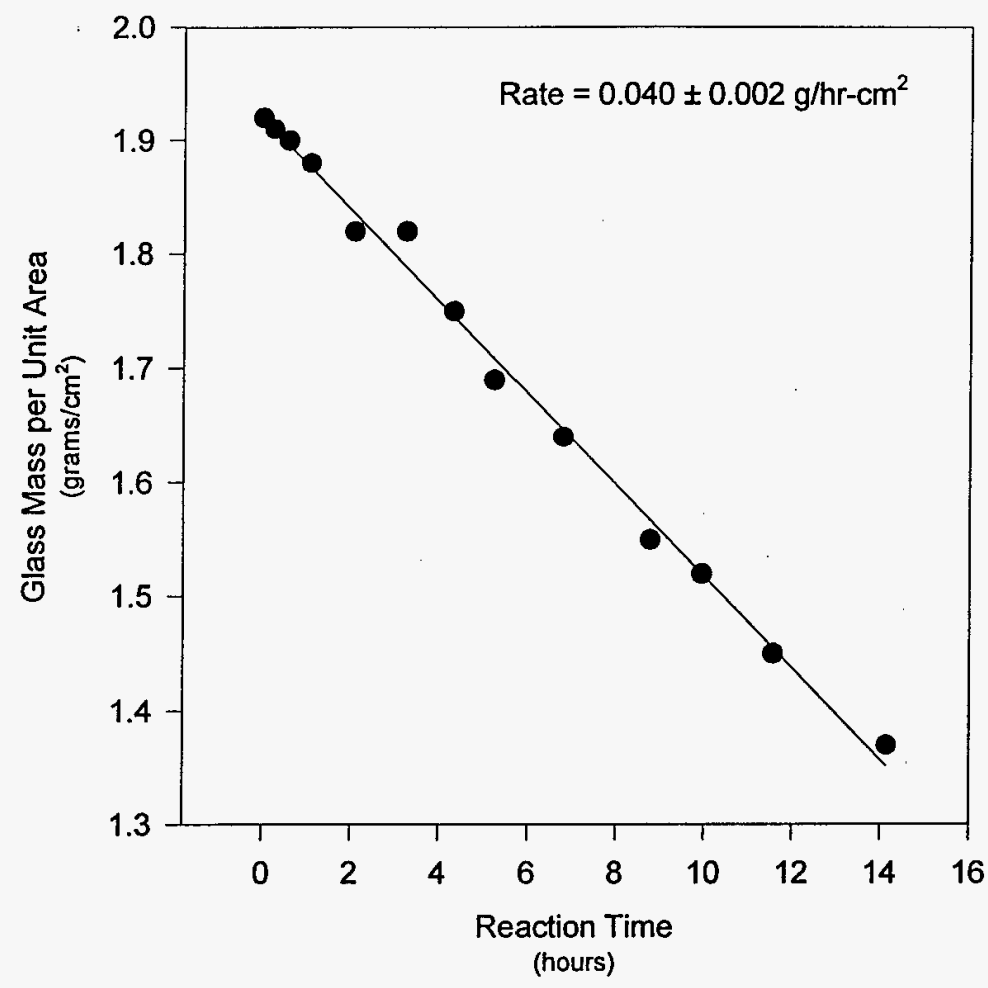

Figure 2 Slow Glass Dissolution

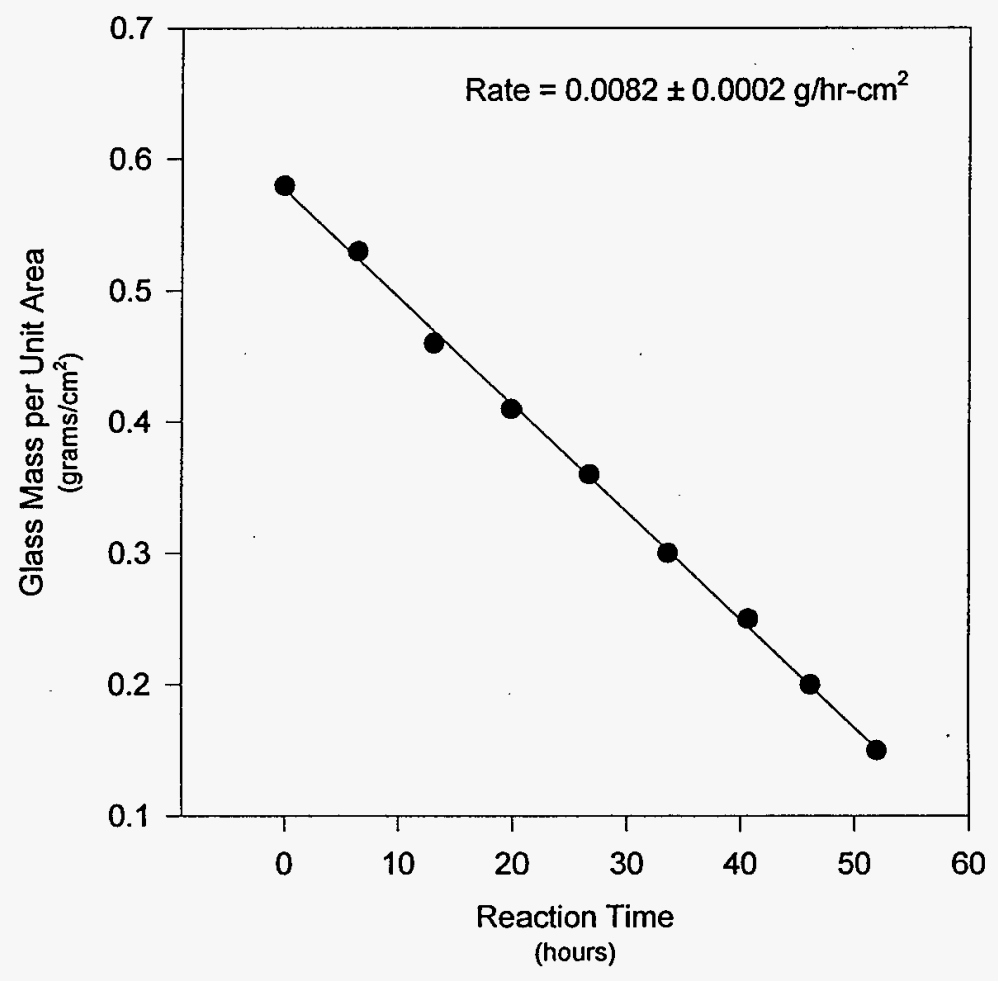


Substituting for the mass $(M)$ and surface area $\left(S_{A}\right)$ in terms of the particle diameter $\left(D_{0}\right)$ and density $\left(\rho_{g}\right)$, followed by integration, yields an equation for the time $(t)$ required for complete dissolution of the glass particle (equation 2).

$$
\begin{gathered}
\frac{d\left(\frac{M}{S_{A}}\right)}{d t}=-K_{R} \\
t=\frac{\rho_{g} D_{0}}{6 K_{R}}
\end{gathered}
$$

Assuming the curium-containing glass particles were spherical with an equivalent diameter of $74 \mu \mathrm{m}$ and a density of $4 \mathrm{~g} / \mathrm{cm}^{3}$, the time required for complete dissolution can be calculated from equation (2) as $0.6 \mathrm{hr}$. This value is consistent with the observation that complete dissolution was achieved in $2 \mathrm{hr}$ or less. By assuming spherical geometry and a maximum particle size, equation (2) will overestimate the time required to dissolve the curium glass. The range of particle sizes with an equivalent diameters less than $74 \mu \mathrm{m}$ increases the surface area and the rate of dissolution when compared to the idealized case. The higher molarity of nitric acid used to dissolve the glass also enhanced the rate and reduced the dissolution time when compared to the time predicted by equation (2), although this effect has not been quantified.

\section{CONCLUSIONS}

The feasibility of recovering $\mathrm{Am} / \mathrm{Cm}$ from a LBS glass was demonstrated using a curiumcontaining glass prepared to simulate the composition proposed for stabilizing the $\mathrm{Am} / \mathrm{Cm}$ solution stored in the F-Canyon facility at SRS. After grinding to less than 200 mesh, the glass was dissolved in concentrated nitric acid at $110^{\circ} \mathrm{C}$ in less than $2 \mathrm{hr}$. Elemental recoveries for each glass component following the extraction were essentially $100 \%$ except for silicon which remained mostly insoluble.

The expected rate of dissolution, when the $\mathrm{Am} / \mathrm{Cm}$ is recovered, was bracketed by measuring the dissolution rate of a surrogate glass under both static and agitated conditions. In each case, the ratio of the mass to surface area was linear with respect to time. The constant rate of dissolution was used to derive a predictive equation for the time required to dissolve a glass particle of spherical geometry in terms of the glass density, particle size, and experimentally measured rate. The calculated time required to dissolve an idealized curium glass particle was in agreement with the experimental observation that dissolution was complete in less than $2 \mathrm{hr}$.

\section{REFERENCES}

1. N.E. Bibler, W.G. Ramsey, T.F. Meaker, and J.M. Pareizs in Scientific Basis for Nuclear Waste Management XIX, edited by W.M. Murphy and D.A. Knecht (Mater. Res. Soc. Proc. 412, Pittsburgh, PA, 1995) pp. 65-72. 
M97008653

I|||||||||||||||||||||||||||||||||||||||||||||||

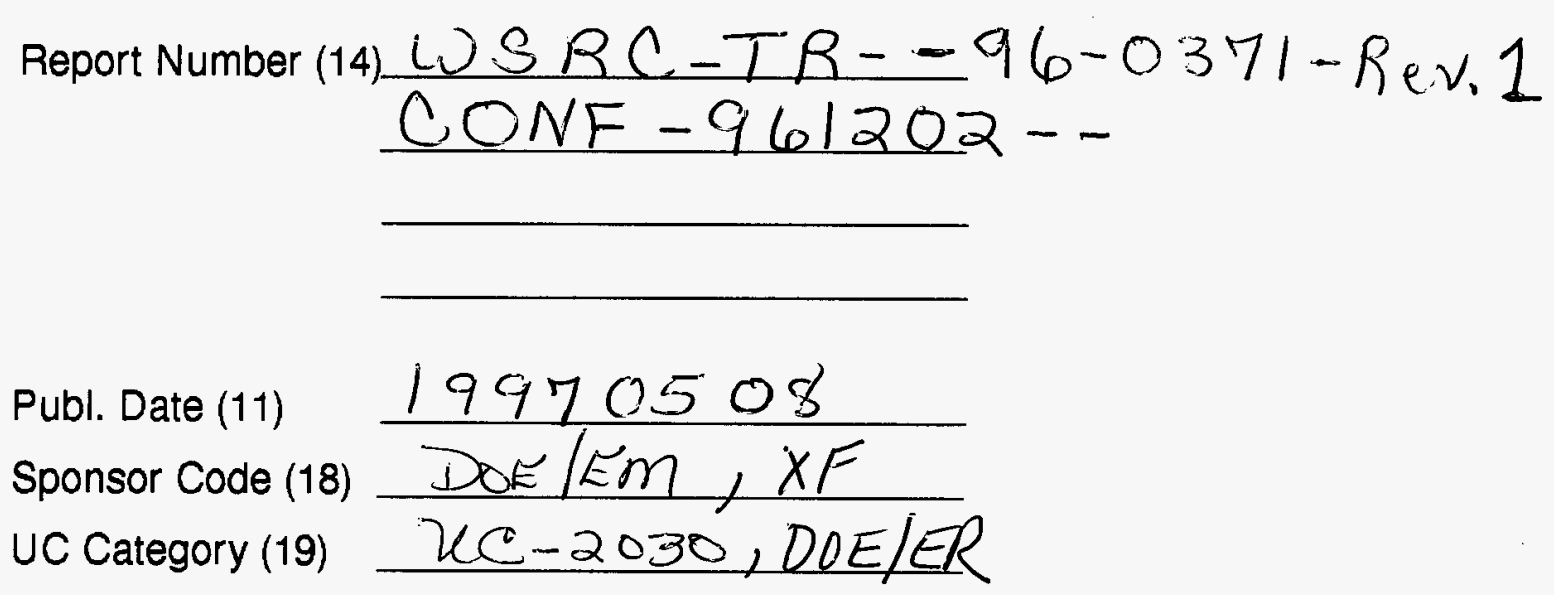

Publ. Date (11) $\frac{19970508}{\text { SDEnsor Code (18) }} \frac{\text { DOE , XF }}{\text { SC-2030, DOE/ER }}$
UC Category (19)

DOE 